\title{
Pilgrimage, Mourning, and Tradition: Commemorative Rituals and Material Responses to the Death of John Paul II in Poland
}

\author{
Michal Mlynarz \\ University of Alberta \\ Edmonton, Alberta, Canada
}

The death of John Paul II in his Vatican residence on April 2, 2005 was a date that had an immense impact upon the world and the Polish nation in particular, as a level of strength and collective unity was put on display that had rarely been seen. It resulted in the pilgrimage of over one million Poles to the Eternal City and the organization of ceremonies of mourning across the country that saw the participation of hundreds of thousands, even millions, of people. In the days following the death, Poles flocked around their hero in an unprecedented way, showing a powerful collective manifestation of modern Polish identity. In the homeland of Karol Wojtyła, the event marked not only that one of the most charismatic and influential men of the twentieth century and the head of the world's largest church had just died - for millions of Poles, a spiritual and national father had died, seen as a saint in the making and as the man who had led his people from the tribulations of centuries of dark history, leading them towards the forging of a new destiny and identity. Millions wept, lit candles, and organized marches and masses that saw attendance rise to the millions, many of them preparing for the long journey to Rome to pay their final respects to their hero. According to Piotr Wyrobiec, Director of the Cultural Centre in Wadowice, 'for Poles, his death was a time of quiet vigil, recollection, inconsolable grief, and spirituality which spread all over the country. Few remained indifferent. This collective experience made us a united community. During that week, "dying" gained a new, deep meaning. The world came to a halt, and the old rules governing our lives were no longer valid.'(1) These days were indeed marked by a collective period of remembrance, grief and commemoration. Poles of every social and political leaning worked together as a strong sense of unity and community was created throughout the country. As Britons had marked the death of Diana several years before, Poles engaged in a flurry of 'obsessive' mourning activity, including the signing of condolence books, the leaving of personalized notes, and the placing of flowers at makeshift shrines, thus marking the period with a spirit of communal social action [Johnson 1821]. The days leading up to one of the most important funerals in history 
also provided many Poles with the chance to collectively express their solidarity and national pride in a new manifestation of an old form - the pilgrimage. Although a part of religious culture for millennia, this pilgrimage differed in that it truly was a national one, where millions of Poles descended upon the Holy See not only to pay respects to their greatest hero and someone who was already widely being considered a saint, but also to express a united sense of identity, the strength of which was noted only a few times before in history, the last being in October 1978, when John Paul was elected to the Papal Throne. The death of John Paul led to the organization of collective movements millions strong, breaching social divides that until that point, and since it, have continued to linger. The aftermath of this day reverberated through every echelon of Polish society. It not only led to a thoroughly impressive and unprecedented united community of Poles from every corner of the nation, it also worked to permanently re-draw the lines of belonging, identity, and memory in the new Poland. Every social and cultural group, every settlement, every form of popular culture, and every period of history was, in some way, connected or re-connected with the image of John Paul II. This paper, largely based upon original fieldwork conducted in Poland and Rome in the summer of 2006, will examine this mass pilgrimage and the mourning practices that were held en masse throughout the country following the death of John Paul, and will look at artifacts of mourning, in particular, 'spontaneous shrines' and other material responses to death that were produced in its aftermath, analyzing them as modern, primarily urban manifestations of folklore.

Throughout its history, the Eternal City of Rome has undergone many periods of turmoil, destruction, and change. The Rome of 2005 was much like any other major European metropolis of the time, bustling with the activity of locals, crowded motorways, and hordes of tourists seeking to view the glories of its bygone past. The death of the first Polish pope in the heart of the city, however, brought on yet another radical phase of change, as millions of pilgrims from around the world flocked to the city and the heads of state of many of the world's nations made bids to be represented at the funeral of this 'man of the century.' Vatican officials estimated that some three million people entered the city during the week following John Paul's death [Walsh 17]. Several days after his death, his body was displayed in state in the Clementine Hall of the Apostolic Palace, from where it was moved into St. Peter's Basilica for public viewing. By April 6, there were about 1.2 million people lined up to see the body. This line stretched for two kilometers, 
with people having to wait an average of sixteen hours to see it.(2) The representatives of over 140 nations were present, including US President George Bush, Prince Charles and Tony Blair of Britain, Ukrainian President Viktor Yushchenko and Robert Mugabe, President of Zimbabwe [Walsh 22-23]. The city had become a microcosm of the world, with NATO warplanes regularly circling the city as millions of world citizens slept in its streets.(3) So many Poles had descended upon Rome that many Italians had felt that the city had become 'a second Poland'.(4) It was his death and the placement of his body into state in the largest Catholic shrine in the world and the subsequent period of collective mourning, massive influx into Rome, and material reminders of these days entrenched within Polish collective memory that have all served to transform John Paul into a Polish 'national totem' (5), also serving as a unique opportunity for Poles to display a large level of both collective and individual response to the event. Across the world, sudden or unexpected death has been marked not only by the private mourning rituals of friends and family members, but also through a collective air. This has been particularly the case in the material phenomenon referred to by folklorists as the 'spontaneous shrine' [Santino 1-17]. These shrines are an amalgamation of diverse elements, including flowers, candles, photographs, poems, written prayers, and other personal mementos [Greenhalgh 43, Santino]. They share many common attributes, incorporating diverse multi-cultural, religious, and political sources [Greenhalgh 43]. Jack Santino claims that an element of 'performativety' can be found in each of these shrines, through which social issues can be examined and questioned, people can be rallied to action, and political issues surrounding the death questioned [Santino 1]. Many such shrines were erected in Poland following the death of John Paul. They, and related artifacts (including books of condolence, grieving cards, photographs, and news clippings) have become one of the most prevalent material markers of the death in Poland and abroad. They were created by people from around the world and from different social and cultural classes, and were left in streets, museums, church and apartment windows, and on the sides of roads.

The pilgrimage is an activity fundamentally connected to the history and life of religious movements the world over. Through it, traveling pilgrims are able to make a personal and emotional connection with their faith, enriching their own sense of spirituality as well as embarking on one of the more significant journeys of their lives. Pilgrimage has regularly been a fundamental component of the Roman Catholic faith. 
Many of the earliest Catholic pilgrimages were often directed at shrines, usually containing the body or other relics of a saint, which were then revered and used as a spiritual focus. This practice has carried on into the present; with modern pilgrimages frequently focusing upon the bodies of famous people. Visits to their tombs are often seen to be personal visits with that individual [Maniura 6-7]. During his funeral, the world media broadcast into millions of homes worldwide the calls of the assembled crowd of Santo Subito - 'A Saint Quickly!' Since that time, calls to make him a saint have been common the world over.

Since the thirteenth century, pilgrimage as a popular form of religious movement has been common in Poland. It was at this time when a cult of native Polish saints, beginning with the canonization of St. Stanislaus in 1253, began. Since this time, pilgrimage in Poland has become a strong aspect of its religious culture [Kłoczowski 44-46]. The pilgrimage to Rome, which saw millions of people visit the city in the time span of less than a week, marked a milestone in the history of the Roman Catholic and Christian church. It also marked a milestone in Polish history. Although political, economic, and national movements, in particular over the past few turbulent centuries, were frequent in the annals of the Polish nation, 2005 marked the first time that so many Poles had joined and traveled in unison to one specific goal in such a short period of time. In contrast to many of these previous movements, this pilgrimage was actively encouraged by the state, now working in unison with the church. Despite the influence of these official structures, Ewa Klekot argues that, in Poland, activities organized by the Church were always seen as 'spontaneous' and natural, often feeding off of what people had already been planning to do, thus giving these activities further impetus [Klekot 5]. Periods of national calamity can often lead to the 'spontaneous' organization of movements and protests the world over, lending themselves to rich ethnological and folkloric study. For example, the 2004 commuter train bombings in Madrid led to a process of 'civil sacralization,' wherein millions of people aggregated in places affected by the bombings, organizing themselves via popular mediums of communication, including SMS text messages and emails. Folklorists studying this phenomenon later catalogued and examined the many shrines and testimonies of participants [Sánchez-Carretero]. In a similar fashion, mourners throughout Poland and Rome used modern technology to organize their activities, oftentimes bypassing the authority of the state to do so.(6) 
In the hours and days leading up to the passing of John Paul, and in particular after his death on April 2, Poles throughout the country took to the streets in record numbers. Churches and cathedrals were filled to capacity at all hours of the day and night, candles and wreaths were left on streets and beneath monuments, and marches and services were organized that numbered in the tens of thousands. In larger cities like Warsaw and Krakow, they reached over a million participants. I argue that these rituals were for Poles 'dramatic social enactments', wherein participants could take part in a public display containing an agency of transformational power [Santino 6-7]. The placement of flowers, cards, and other personal mementos in what are otherwise 'secular' areas of public space can serve to turn the daily spaces of life into a temporary community [Greenhalgh 52]. This period of mourning, held between April 1 to 8, was widely known as a 'Second Easter' and a 'Week of Vigil' [Klekot 3]. Entire streets in many cities were converted into temporary 'spontaneous shrines', often combining elements of an 'official' period or level of organization with that of a true sense of spontaneity, friends following friends and family members into the streets. This event was not only one where people were able to express grief, it also functioned as a time for society to collectively manifest and express shared feelings, in the process asserting a certain level of autonomy from the government [Klekot 3-6]. In this sense, Poles used the performance of ritual, 'spontaneity,' the erection of shrines and collective moments of prayer and reflection to 'sacralize' public space throughout the country. The streets of the capital, including the entire four-kilometer length of John Paul II Street, were lit up with countless candles and lanterns.(7) Particularly on this street, many 'shrines' were created, left especially by street signs [Klekot 5]. Shrines were left throughout public space as 'offerings,' intended as 'his individual property,' in the form of flowers, candles, flags (both national and papal), handwritten messages, cards and letters, and portraits or 'homage boards' [Klekot 3-6], with entire streets being turned into sacral ground and one extended 'spontaneous shrine.' By late April, when the flowers, candles, and lamps had begun to be cleared out, several tons had to be removed daily. Twenty-five tons of lamps were removed from the Church of St. Anne alone.(8) In Piłsudski Square, over 300,000 mourners, a group that included many professional workers leaving their offices for the occasion, congregated in order to attend a celebratory mass.(9) In Warsaw, Polish journalists had their own mass in honor of John Paul on April 10.(10) Similarly large gatherings were held 
throughout the country. In Krakow on April 4, over 150,000 people marched together through the streets of the city in a 'memorial march'.(11) Shortly after the announcement of his death, thousands of people marched to the Błonia fields, where during his last visit to Poland, John Paul had held a service for 2.5 million people.(12) Similar marches were organized throughout the city.(13) On April 7, over a million people participated in a 'White March' through the streets of the city, dressed in white and carrying candles. Similar marches had been held during each of John Paul's pilgrimages to the country, as well as in the aftermath of the assassination attempt in 1981.(14) Cities regularly saw the 'spontaneous' organization of large memorial marches and the lighting of candles and lanterns. On April 4 in Tarnów, several thousand inhabitants of the city congregated on John Paul II Street in order to leave candles and lanterns there.(15) On April 6, 20,000 mourners gathered in the Town Square to attend a service.(16)

Public areas throughout Poland were, during this time, given a certain 'Van-Gannepian' sense of liminality. In Warsaw, Klekot's informants claimed that a number of 'moral miracles' had taken place, ranging from a general (and uncommon) feeling of safety in the streets of the capital at night, a lack of rowdy and drunken behavior, and the return of stolen cars by thieves [Klekot 5]. In virtually every urban settlement and in every house of worship, from the ornate cathedrals of large urban centers to the smaller churches and basilicas, some sort of service was held to honor John Paul, and many shrines were created, with thousands, tens of thousands, and occasionally hundreds of thousands or even millions of people taking part. At this time, in a process mirrored throughout the country, residents of the town of Swidnia placed pictures of John Paul in their windows and hung Polish flags, tied with black ribbons, to trees.(17) Mourning also took on a more 'traditional' and rural nature. For example, on April 4 in Wał-Ruda, a small village with a population of about 600 people, a group of 3000 embarked on a procession of the Way of the Cross, following the route of the blessed martyr Karolina Kózkówna and reciting John Paul's teachings along the way.(18) In the northern Baltic port of Kołobrzeg, sailors lowered the flag to half-mast in memoriam.(19) The leaving of temporal ribbons and related items also speaks of 'performativety,' allowing individual members of society to memorialize the event and place, using different materials and colors in order to both commemorate the loss as well as to engage with the current political and social climate [Santino 8-10]. People drew upon diverse elements of their cultural tradition in order to 
express their grief and to negotiate their identity as Poles. On April 3, TV Polonia featured footage of mourning from throughout the country, including in the culturally-distinctive area in the north of Poland, Kashubia, where prayer sessions were held at the Kashub shrine in the town of Sianów.(20) Three thousand Tatra highlanders from the Podhale region came to Zakopane in order to attend a commemorative service for the pope in the Church of the Fatima, famous for its unique architectural style.(21) Amongst the forms of remembrance that they followed was the playing of violins and the singing of traditional songs from the region.(22)

The death also created a sense of unity between Poles worldwide. Amongst the large Polish diasporas in Western Europe, a march of 12,000 was organized through the streets of London, with smaller ceremonies being held in Oxford, as well as in Dublin's Phoenix Park.(23) The death of John Paul sparked an unprecedented period of mourning that saw millions of Poles grieve in the streets. It also saw people from every walk of life making the decision to travel to Rome and to the funeral of John Paul in person. Since he would not be buried in Poland nor would his heart be interned there, the funeral for one of the greatest Poles in history would be held in the Vatican, and it would follow the rigors and rituals of the Holy See's centuries-old tradition, with journalists, citizens and heads of state the world over being present for the event. Such an atmosphere created a strong sense of a united community amongst the Poles temporarily resident in the city. In a Gazeta Wyborcza report, one correspondent relates how there were so many Poles in the area and so many Polish voices, that they felt right at home. The number of Polish flags and people led the Italian police patrolling the area to comment that 'everything is Polish'.(24) The concept of a 'second Poland' amongst Italians was regularly echoed and noted.(25) Certain individuals personified this sense of 'spontaneous' cultural, religious, and patriotic expression. One man profiled on Polish media had camped out in St. Peter's Square with a large Polish flag, on which he was collecting messages and signatures. By April 4, he had already collected over 100,000 , and was planning to take it to Jasna Góra, a shrine housing the famous Icon of the Black Madonna and a place that, although engrained in a deep tradition of pilgrimage and reverence, has taken on strong cultural and patriotic connotations over the past few centuries.(26-27) The pages of Catholic journals produced at the time frequently chronicled the experiences of individual groups of people from different parts of Poland and how they interpreted their 
experiences. The Catholic periodical, Sunday Guest, produced reports from each of its dioceses, many of which can be viewed online at http://goscniedzielny.wiara.pl. From a general reading of samples of different diocese reports, there frequently appears to have been a 'spontaneous' initiative amongst groups of family, friends, or school and church groups to journey to Rome soon after they heard of the death. This 'spontaneity' characterizes many of the accounts.(28) Also common was a strong sense of unity and national feeling amongst the different groups of Poles during their time spent in Rome, taking comfort from and gathering amongst others speaking their language, singing their songs and waving their flag.

During the pilgrimage, the halls of the Polish Home were packed to capacity. Ten people slept side by side on the veranda, and sleeping mattresses had been laid out even in the laundry room.(29-30) In museums like the Polish Home and in the streets of cities, the parallel processes of how different 'vectors' of collective memory play out and interact with each other can be observed. The pilgrimage led to the temporary union of millions of Poles, but it also led to the permanent production of tangible reminders of that fact. Material responses to grief can be analyzed by the folklorist for modern cultural information and beliefs, much as grave goods or other artifacts can be examined by an archeologist in their study of the past [Grider 215-229, Thoms]. The Polish Home maintains a large collection of materials produced during and after April 2005. These largely consist of written works such as letters or books of condolence, expressing sorrow and personal feelings following the event. The largest such book is located inside the entrance of the Home, and, at the time of my visit, contained 236 pages of signatures. Many of the entries are written by young Poles and are couched especially in religious language and in terms of thanks. There are many elaborate entries, including poems, prayers, and illustrations, many of them employing religious imagery, photographs and newspaper clipped images and stories of the pontiff, demonstrating a great range of creativity by young and old alike. There are various non-Polish entries, as well, including several written in English, Italian, German, and Spanish. There are entries from members of the Polish diaspora in North America and Europe, and other entries from places as diverse as Los Angeles, Cologne, Colombia, Texas, Mexico, and Saudi Arabia, thus illustrating the global connection of Poles around the image of John Paul, as well as the more general feeling of worldwide mourning and response. One of the more interesting entries to take on a religious and patriotic 
tone was contributed by a Pole from London, who pasted in a picture of the Lady of Częstochowa.(31-32) There are several other condolence books in the archives of the Home. One of the most significant is a collection of 1.2 million signatures from the popular Polish Internet site ONET.(33) There are several other books of condolence at the Home, including one from the children of Bielsko-Biała, a volume from Błonia, a volume from a Polish parish in St. Louis, USA (demonstrating how Polonia organizations around the world rallied around his image as a personification of Polish identity and culture), and one from San Antonio, Chile. Several other books were sent in from parishes and organizations throughout Poland, including one from a Union of Combatants and former Political Prisoners, as well as a letter exchange between Błonia and its sister city in Italy, Coreno.(34) I also found a number of condolence books in Krakow's Archdiocesan Museum.(35) Stanislaus Dziwisz, former aide to John Paul and sponsor of many photographic exhibits throughout the country, also contributed several of these post-death documents following the funeral.(36) In this fashion, the pilgrimage will be permanently marked and remembered within the halls of the Polish Home and for the many Poles and non-Poles who have, and who will continue to, visit its halls. It will be remembered long after the 'Polish city on the Tiber' is gone and when the English of British and American tourists once again becomes the second most commonly heard tongue on the streets of Rome.

In terms of reminders of the pilgrimage, likely the most numerous and detailed would be the many photographs, videos, and memories of the event in the homes and minds of its participants.(37) The Internet and its many mediums of communication likewise revolutionized the ways through which a pilgrimage could be conducted. Personal 'blogs', reminiscences, and personal websites can be found all over the Polish internet, offering a powerful channel for participants to express their personal sense of grief and interpretations of the 'Week of Vigil'.(38) The streets and squares surrounding St. Peter's bear no material reminders of the millions of people who once slept there, of the many flags and lighted candles, lanterns and photographs that were left in every niche and corner of the ancient city. Much as in Warsaw, there were many personal tributes left all over the city during this period, but they have all since been cleaned up. Although shrines may only be temporary, they are able to visually mark a place with a more permanent sense of collective and emotional meaning and a sense of memory for people not present during its creation [Hartley 297]. In the realm of 
'tangible memory,' the best collection can be found in the Polish Home. However, I wandered through the streets of Rome in an attempt to find any material reminders of this time, to see whether any makeshift shrines or memorials still stood. The only memorial that remained was John Paul's tomb itself in the grottoes of St. Peter's.(39) From my observations, it appears that the most representative artifacts of this time in Rome are clichéd photographs, designed for the mass consumption of tourists. The market stalls of the city were filled with magazines, calendars, postcards, and photographs of Giovanni Paulo. Many of them displayed continuity between John Paul and his successor, Benedict XVI. One stand sold trading cards, postcards and photographs of the late Bishop of Rome next to tacky gladiator toys, Rome pencils and buttons.(40) The tourist image of John Paul conflicts sharply with that of the Roman and Italian people, who hold a much more reverent attitude.(41)

There are a number of Polish churches and organizations in the city of Rome representing the small Polish communities living in the city and country. I visited these churches in order to inquire into and examine any mementos or artifacts produced during the 'Week of Vigil' that may have found their way into the parishes or their archives.

The first church that I visited was the Chiesa di Santo Spirito in Sassia, or the Church of the Holy Spirit, located on 12 Via dei Penitenzieri, Vatican. This church is not officially Polish, but maintains a strong association with John Paul and with Rome's Polish community because it was the place that saw the beatification of Faustina Kowalska by John Paul, and serves as headquarters for the Divine Mercy movement. There is at least one Polish nun resident at the church, and at the time of my visit, there was a Polish family standing outside its door. In exploring the Church and speaking to the Polish nun, however, I found no material traces from the pilgrimage.(42) Another church in Rome, which is much more prominent and well known to the Polish community, is St. Stanislaus Church, located by the Via dei Polacchi (Road of the Poles.) This church plays a strong role in the life of the Polish-Italian community, both in its connections with John Paul and with the pilgrimage and Polish identity itself.(43-44)

As is common throughout the world, the great men and women of East-Central Europe are remembered and regarded in many different mediums. The popular Habsburg emperor, Franz Josef II, had his likeness fashioned into candy in 1908 by a Lwów candy maker, and a marzipan image of him could be found in Vienna shops in 1997 
[Unowsky 1-3]. For his Jubilee, admirers could purchase everything from knives and carpets to ashtrays and bread-crumb-grinders with the emperor's visage [Unowsky 125]. Throughout the world, leading social and political figures are frequently portrayed in the popular, 'folk' context (for example, 'marushka' dolls created in the image of Soviet leaders, or the graffiti 'portraits' of Honecker and Gorbachev painted on the Berlin Wall). Shortly after the death, the Institute of John Paul II in Krakow received a large donation of items, including books of condolence, drawings, Polish and regional flags, and football 'supporter' scarves. The Institute, founded in 1995, seeks to document especially the Krakow period of his life, and has organized over 20 exhibits connected to his life.(45) In the town of Radom, a local artist constructed what he hoped would be the largest book of condolence in the country, weighing over 250 kilograms and measuring two meters high by one and a half meters wide, intended for donation to the Family Home Museum in Wadowice after it had been filled up.(46) Towns and communities throughout the country also frequently preserve their physical memories in museums and displays, thus creating local versions of collective memory of the death and pilgrimage for generations. In the town of Bochnia, close to Krakow, a large banner was put on display at the museum with the inscription 'Meeting with John Paul', a place where these mementos were aggregated. There was a 'spontaneous' march of about 20,000 people in the town's square after the death, where a large papal flag was put on display for people to sign. It has now found its way into the collections of the museum.(47) Similar observations can be made for larger cities.(48) One year after his death, buildings and windows throughout Poland had all sorts of reminders of John Paul on prominent display.(49) Photographs are regularly employed as relics, often standing in for the essence of the dead [Senie 44]. In Krakow, I saw a photo of the pope in apartment windows,(50) photos, medallions and papal flags with his image amongst votive offerings in the Lagiewnik Sanctuary,(51) and newspaper clippings tacked onto trees outside the Franciscan church. As might be expected, the entire town of Wadowice, John Paul's town of birth, is filled with such visual and 'folk' reminders. Shops and windows throughout the city were also covered with John Paul imagery, including blue and yellow handcut papal insignias in residence windows.(52) The town basilica featured a most interesting tribute from the Podhale highlanders, a 'nativity scene' that included a mannequin dressed in traditional highlander clothes, surrounded by lambs and the motto 'Faithful Shepherd', illustrating yet again how 
different groups in modern societies can draw upon folk motifs in the expression of modern political sentiments.(53) In the Tatra mountain town of Zakopane, I found numerous local tributes, including photographs from John Paul's funeral on the walls of the Church of the Fatima,(54) a small statuette in the niche of the cemetery walls,(55) and a symbolic 'tomb' located outside the Church of the Fatima. Although I am unaware of the circumstances or history behind the creation of this 'tomb,' it is possible that it could constitute a 'symbolic heart,' perhaps being used as a center of pilgrimage for people unable to travel to Rome.(56) Even if it had been erected by church authorities, as Klekot describes, such actions would still retain a large measure of 'spontaneity' and individual creativity [Klekot 3-6]. It also stands as an excellent example of a more permanent variation on the spontaneous shrine, and incorporates many folk elements, including traditional highland architectural motifs, folk art (the statuette found inside the shrine is reminiscent of many Polish and Slavic wood folk carvings), as well as religious emphasis (including the Latin tomb inscription and miniature copy of the Vatican grave). Not far from the church, I found a most interesting roadside shrine. In traditional Polish religious culture, these shrines usually demarcated the limits of a village, often being established at their crossroads, additionally serving to facilitate social interaction and veneration [Benet 181]. What distinguishes this shrine from many others, however, is that rather than the image of a saint, Christ or the Virgin, it has a photograph of John Paul, looking contemplatively at the viewer, surrounded by candles, flowers, and a Polish flag. The relatively recent phenomenon of building statues as markers of national identity has its origin within religious tradition, with many of the same activities being conducted at each, including the lighting of candles and the laying of wreaths; the national shrine (or monument) thus acts as a secular form of the worship of national ideals [Paces and Wingfield 122-123].

In the aftermath of Princess Diana's death, a more permanent shrine was created for her by a multitude of mourners on a Paris freeway [Banks Thomas 22]. She had become a symbolic figurehead, her image available to a large and diverse public, functioning as a strong symbol of 'British-ness' around which the nation could consider itself more of a homogenous whole [Johnson 24-40]. Material remnants left behind at these shrines, such as poems accompanied by British flags, made their 'English-ness' evident [Johnson 48-49]. Sylvia Grider considers the artifacts left behind at spontaneous shrines to be manifestations of both the social background of the people who had left them there, as well as 
excellent sources of cultural information, being drawn upon by folklorists much like a present-day archeologist, studying it in order to better understand modern cultural significance [Grider 215-230]. Different artistic sentiments can be analyzed in the study of these shrines (for example, the choice of photographs and poems left behind), as well as senses of patriotic obligation (such as the selection of flags) [SánchezCarretero 333-343]. In a similar fashion, the death of John Paul led to a wide recognition amongst Poles of his image as one to unite around, where they were able to express a collective sense of solidarity and creativity in their selection of visual markers and artifacts. As was done throughout Madrid, certain elements of shrines can be employed to express one's regional or national identity, negotiating through creative channels one's own perception of national identity [Sánchez-Carretero 339-347]. This shrine, then, perhaps best personifies the many ways in which the people of Poland marked this transformational period in their history. The establishment of it marks both an awareness of and appreciation of custom and tradition. It also marks an expression of religious and patriotic feeling, found both in the image and in the flag. The lines between faith, tradition, patriotism, and national identity are thus blurred and made into inseparable elements, whereby they can all be simultaneously expressed at a single place and time, centering them on the image of the Polish Pontiff.

This has been made evident throughout Poland, but it is perhaps even more poignant around a roadside shrine, taking, and manipulating, an ancient symbol of folk culture and religion, and using it in order to express a strong sense of national identity and pride. 'God, Honor, and Fatherland' - this is a phrase that can be regularly found in the pages of Polish nationalist writings. Is this shrine then a way for the people of Poland to express their own understanding of this concept, of their faith, culture, and of their devotion to the nation and its heroes?

Following the death of the first Slavic pontiff to occupy the throne of Saint Peter, an entire nation rallied around his image. In this time of mourning for their national hero and father, Poles expressed a strong collective sense of identity, one that was largely articulated through the mediums of pilgrimage, group mourning, and prayer, the leaving of material tributes and the construction of makeshifts shrines. Although they became the subject of intensive public debate and media coverage, these collective actions and material tributes have helped demonstrate how the death of a national figure functions on the 'ground level' of the people, giving millions the chance to express their own sense and 
understanding of their society and culture. The death of John Paul II has given scholars the unique opportunity to study politics and national sentiments and to observe a culture and belief system in transition. Such scholarly work shows how traditional culture can be used to express a new sense of identity on both a local and an international scale. The image of the world's first Polish Pope served as a focal point for the Poles. We can use it also to help illuminate contemporary Polish culture.

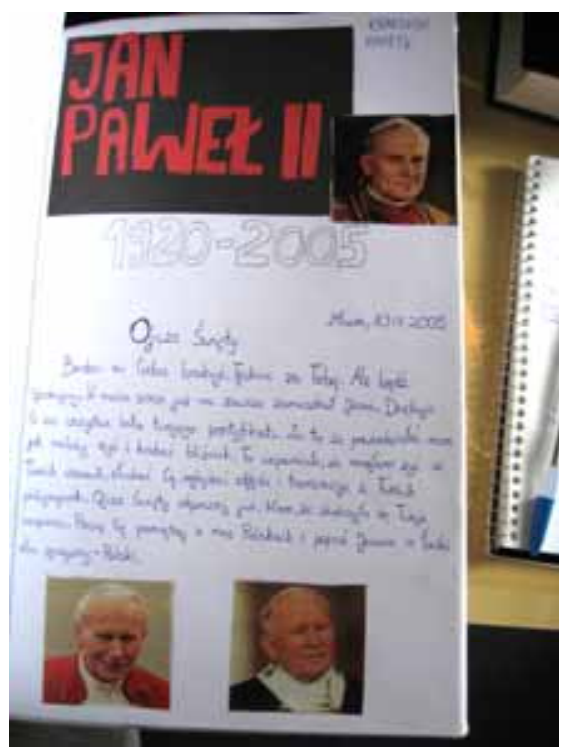

From a book of condolences sent to the Polish Home in Rome. May 10, 2006.

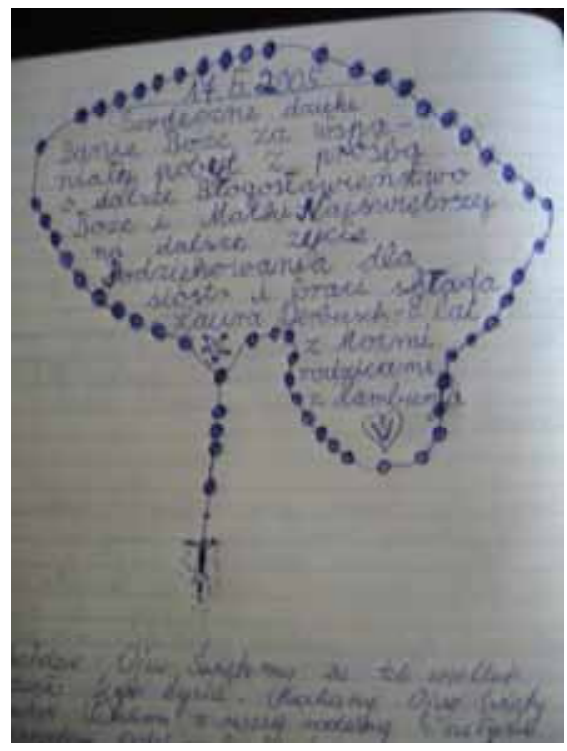

An entry in a book in the Polish Home. May 10, 2006. 


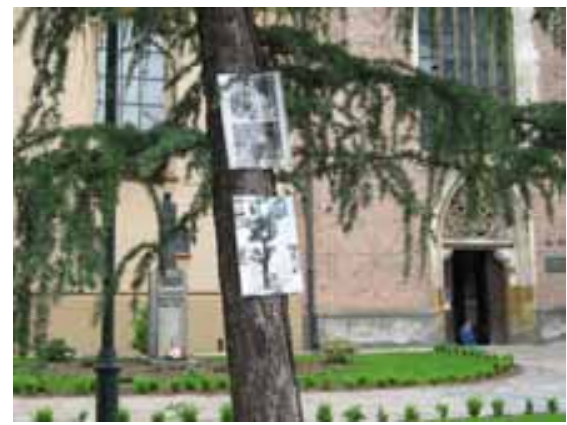

Newspaper clippings outside the Franciscan Church in Krakow. May 23, 2006.

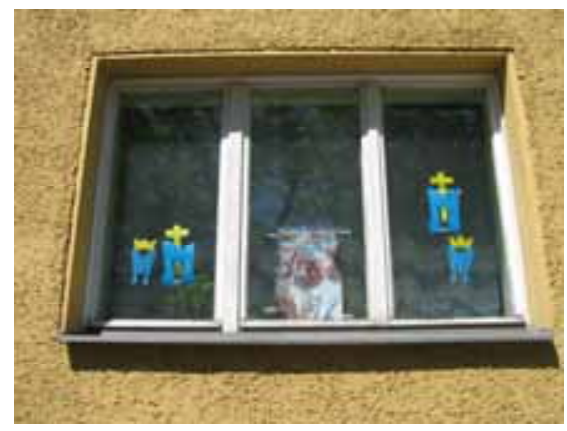

A residential window in

Wadowice. The 'M's are handmade representations of John Paul's papal insignia. May 22, 2006.

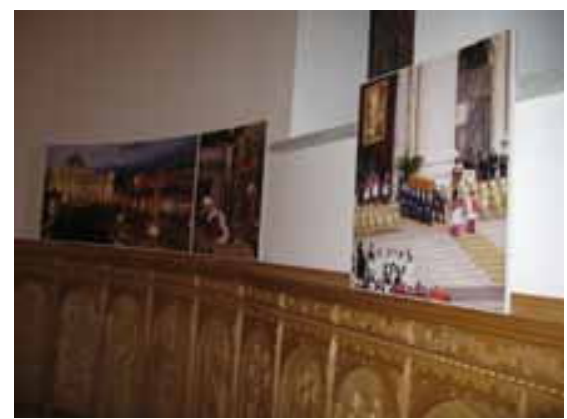

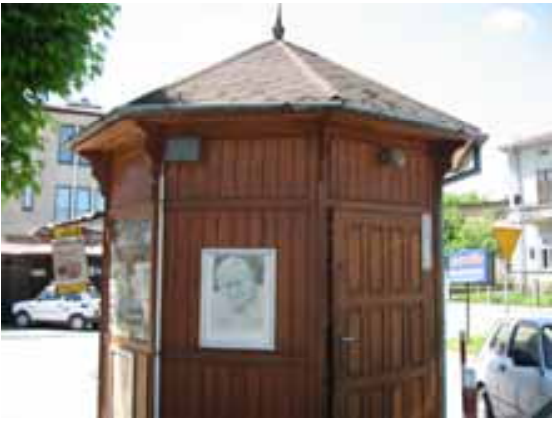

A portrait of John Paul on an outdoor kiosk in Wadowice. May 22, 2006.

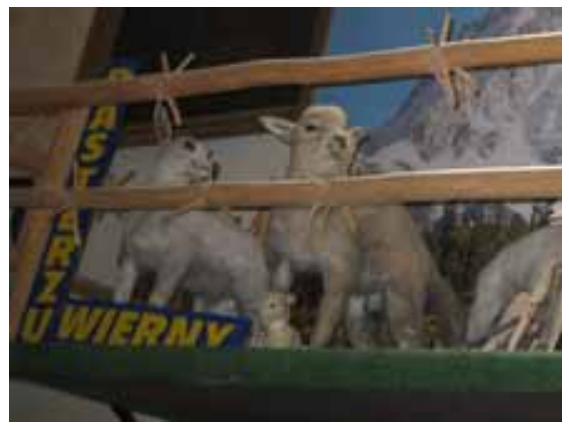

Text (which reads 'Faithful Shepherd') in Wadowice's Minor Basilica, where John Paul was baptized and received his first sacraments. May 22, 2006.

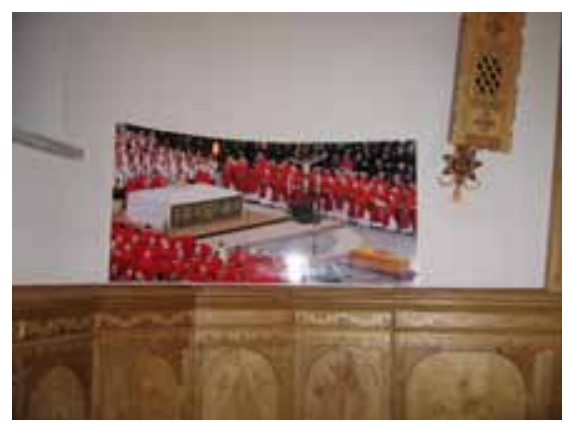

Photographs of the funeral in Rome, on the walls of the Church of the Fatima, Zakopane, Poland, May 28, 2006. 

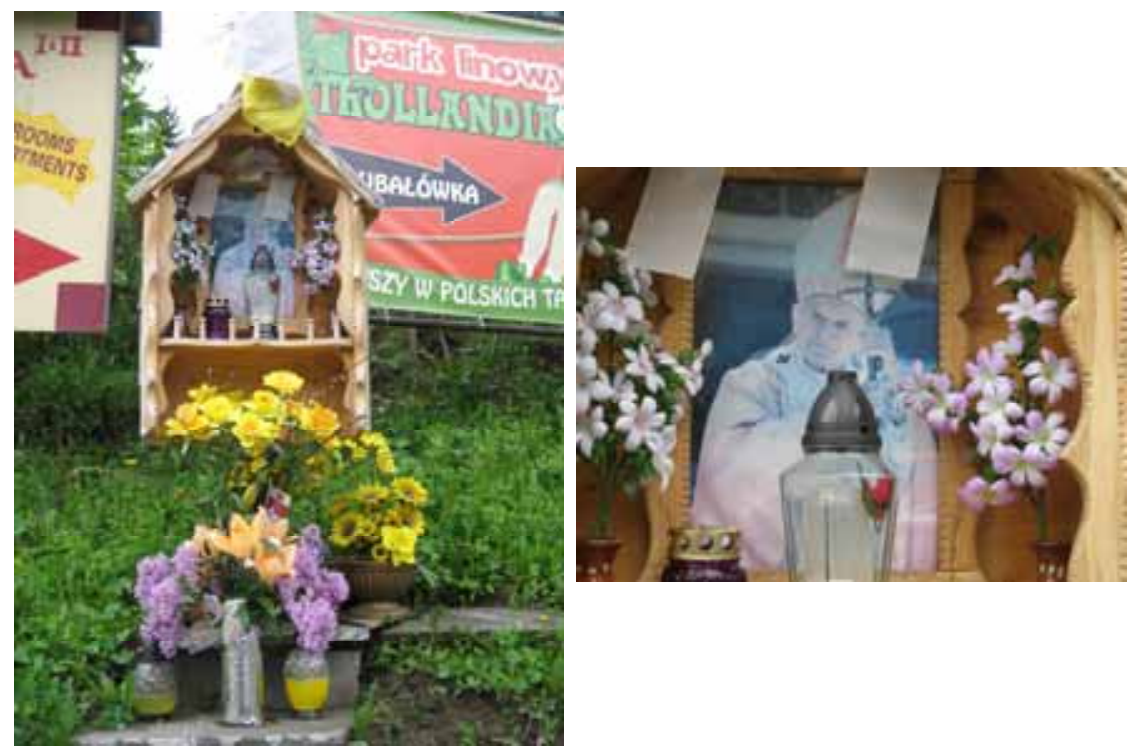

The John Paul 'wayside shrine', found in the town of Zakopane. The shrine is built in a 'traditional' highland fashion.

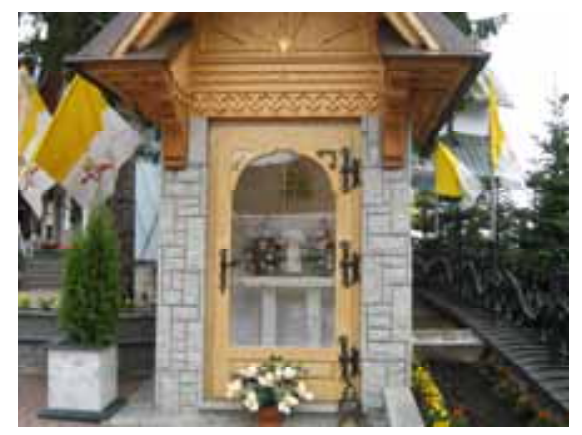

The 'Santo Subito' -'A Saint Quickly'

Shrine, Zakopane, Poland, May 28, 2006.

\section{NOTES}

1 I looked for you, Now you have come to me: John Paul II at the end of his way, Exhibition of the photographs Agence France-Presse, Wadowice, Town Museum, 4 Kościelna Street, At the first anniversary of his death (The Cultural Center of Wadowice in the name of M. Wadowit: Wadowice, Poland, 2005), 6-7. 
2 TV Polonia News Release, Telewizja Polska SA, Warsaw, April 6, 2005.

3 TV Polonia News Release, Telewizja Polska SA, Warsaw, April 7, 2005.

4 TV Polonia News Release, Telewizja Polska SA, Warsaw, April 8, 2005.

5 As described by Katherine Verdery, the bodies of national heroes in East-Central Europe were frequently utilized by advocates of nationalist movements, connecting their image and often elaborate funerals to a nationally inspired cause, thus turning the dead hero into a symbol of the nation (Verdery 1999).

6 For example, various Sunday Guest (a popular Catholic periodical, which contained many reports on the commemorative activities of Poles during this period) reports related how people used email and text messaging to organize carpools to Rome, to turn off all their lights at a particular moment, or to come down to a town square, church, or street in order to collectively mourn.

7 "Lampy czuwających," Gość Warszawski 16(329) (April 17, 2005).

8 “Tony wypalonych zniczy," Gość Warszawski 17(330) (April 24, 2005).

9 Gołąb, Tomasz. 2005. "Narodowa Msza św. na placu Piłsudskiego: Naród żegnał Ojca," Gość Warszawski 17(330) (April 24).

10 “Ks. Niewęgłowski podziękował mediom," Gość Warszawski 17(330) (April 24, 2005).

11 "Marsz jedności w Krakowie," Gość Krakowski 16(583) (April $17,2005)$.

12 "Drogowskazy z Błoń," Gość Krakowski 16(583) (April 17, 2005).

13 Wojciech Pelowski, "Kraków po śmierci Papieża - smutny i dobrze zorganizowany,"

http://serwisy.gazeta.pl/jp2/1,72542,2655001.html.

14 "Ponad milion ludzi w Białym Marszu w Krakowie," http://serwisy.gazeta.pl/jp2/1,72542,2642113.html.

15 "Aleja światła," Gość Tarnowski 16(604) (April 17, 2005).

16 "Na sądeckim Rynku," Gość Tarnowski 16(604) (April 17, 2005).

17 “Gesty przywiązania," Gość Świdnicki 16(50) (April 17, 2005).

18 “Wał Ruda”, Gość Świdnicki 16(50) (April 17, 2005). 
19 "Pomorze żegna Ojca Świętego: Usłyszeliśmy Go," Gość Koszalińsko-Kołobrzeski 16(682) (April 17, 2005).

20 TV Polonia News Release, Telewizja Polska SA, Warsaw, April 3, 2005, and April 7, 2005.

21 "Górale modlili się za Gazdę świata," Gość Krakowski 16(583) (April 17, 2005).

22 TV Polonia News Release, Telewizja Polska SA, Warsaw, April $2,2005$.

23 Dominika Pszczółkowska, "Ogromny marsz Polaków w Londynie," http://serwisy.gazeta.pl/jp2/1,72542,2645360.html.

24 "Polskie miasto nad Tybrem - korespondencja," http://serwisy.gazeta.pl/jp2/1,72542,2644118.html.

25 An interesting piece of research would be to examine the Italian reaction to, and understandings of, Poles entering the city during the pilgrimage. Father Jan Główczyk, of the Polish Home in Rome, stated that the Italian perception of Poles is a very positive one, with both nations taking part in a 'spontaneity of life' and holding a shared understanding of the power of the Catholic faith in daily life.

26 TV Polonia News Release, Telewizja Polska SA, Warsaw, April 4, 2005.

27 This individual demonstrates how pilgrims were able to produce unique expressions of their collective solidarity and grief during this 'Second Easter,' manifesting it through a creative and cultural channel. The Icon of Our Lady of Częstochowa is often used as a symbol of Polish identity, both in a more traditional context (for example, as an icon frequently appearing in peasant homes, rural roadside shrines and chapels,) as well as in the modern sense (such as in Polish diaspora (or Polonia) churches worldwide.

28 Although I attempted to get in touch with pilgrims during the course of my research, I was unable to obtain any personal accounts. I sent out a number of surveys to Polish parishes in Rome and to various student and Catholic websites in Poland, but unfortunately received no replies. However, a number of publications have since been produced in Poland chronicling the events that, likely, contain personal accounts. In her article on mourning processes in Warsaw, Klekot, who did interview individual pilgrims, likewise notes that there was a strong sense of 'spontaneity' and of 'unofficial' organization amongst the mourners and pilgrims [Klekot 4-6].

29 The Polish Home in the Name of Pope John Paul II was established in Rome in 1981, and has since served both as a home for 
Polish pilgrims visiting the city, as well as a vast archive and museum of John-Paul-related artifacts and other material markers of Polish identity.

30 Personal communication from Helena Kupiszewska, Rome, Italy, May 11, 2005.

31 Personal observations, Rome, Italy, May 10, 2006.

32 It is interesting to note that, amongst the many contributions to condolence books, many of which expressed personal feelings of loss and mourning, can be found an image that has been significant to the Polish national narrative (and to Polish traditional culture) for centuries. A link can be made between this image and the man collecting signatures on a Polish flag during the pilgrimage. In this fashion, it is demonstrated how both Poles living abroad, as well as in Poland, used this tragic event as an opportunity to express their own sense of cultural and religious identity.

33 The signatures are collected in a 16-volume work of 805 pages, released in three copies, one of which is at the Home. Father Jan emphasized the sheer magnitude of the number of signatures. He stated that although few people in Poland have regular access to or know how to effectively use the Internet, the fact that over a million people signed it shows an event without precedence.

34 Personal observations, Rome, Italy, May 10, 2006.

35 Personal observations, Krakow, Poland, May 22, 2006. This museum, although primarily devoted to displaying artifacts relating to John Paul's time spent in Krakow as archbishop of the city, likewise contained several books of condolence, and was the site for numerous rituals of mourning, including moments of collective prayer and the construction of many 'spontaneous shrines' during the 'Week of Vigil'.

36 Personal communication from Helena Kupiszewska, Rome, Italy, May 11, 2005.

37 During the course of my fieldwork, I maintained a particular focus upon the activities and events of organized institutions, such as museum and photo exhibits. I did have the chance, however, to examine and photograph many permanent reminders of the event, also created in a more 'spontaneous' fashion, such as the collections of the Polish Home. A promising future line of research would be to conduct interviews with individual pilgrims throughout the country, in the process taking note of their photographs, home videos, and other documents and memories of the event.

38 For example, at the time of writing, the popular video-sharing website, YouTube, contains a number of user-produced clips of their 
time spent in Rome. For the most part, they relate personal experiences from the city in addition to news clippings and related images from the time, and, much like private home videos of cultural events such as family weddings or funerals, function as an excellent source for understanding the 'folk' perspective on such events.

39 Although the tomb was closed during my visit, in the immediate aftermath of his death, many 'folk' tributes, such as flowers and photos, were left on it, a practice that is likely continuing on a regular basis. A 'folk' reproduction of this grave, described in this paper, can be found in the popular Tatra mountain resort town of Zakopane.

40 Personal observations, Rome, Italy, May 9, 2006.

41 In many Catholic countries, it is a traditional practice for people to hang religious images in a variety of settings, such as in one's home and on car rear view mirrors. For example, 'ordinary' Romans would hang images of John Paul in their homes, businesses, and cars, much as would many Poles; I saw one such image in my small, two star hotel in the Roman suburb of Ostia. They also regularly call upon and support Polish organizations in the city to conduct more memory work and have organized their own museum exhibits connecting John Paul to the life of the city. A November 2006 news headline stated how a man in the town of Salerno, near Naples, claimed to have been cured of lung cancer after his wife had prayed to John Paul and seen him in a dream ('Un giovane guarito da Papa Wojtyla: L'arcivescovo Pierro rivela il prodiga durante l'omelia alla messa di Ognissanti', Il Mattino, November 2, 2006), demonstrating that for Italians, he is being treated as a saint, but not particularly as a national hero.

42 The church was opened only a few minutes before the mass began. I quickly walked through and took a look around, but did not find any icons, cards, items or any related materials of John Paul, such as votive offerings, in the church. I quietly inquired of the nun as to any such remnants but was told there were none.

43 Much like Santo Spirito, I did not find any artifacts or physical mementos of John Paul or of the pilgrimage inside this church, excluding a portrait of him in the sanctuary. Although there was a nun resident in the church at the time, she was not aware of any tangible elements that I could potentially examine. It would appear that the best places to find tangible elements of this pilgrimage would be in museums, people's homes, and in other places of national significance, such as Jasna Góra, where 'folk' tributes are often left. Following the 2004 terrorist attacks on commuter trains in Madrid, a great number of the shrines and tributes 
that had been created in the aftermath were photographed, digitized, and made available on various online archives [Sánchez-Carretero]. Like the Madrid tributes, numerous 'online shrines' can be found, where people can light virtual candles for the Pope, leave messages, and engage in other mourning and commemoration practices.

44 "Gdzie modlą się rzymscy Polacy," http://serwisy.gazeta.pl/jp2/1,72542,2636119.html.

45 "Papieskie pamiątki: Do Instytutu Jana Pawła II," Gość Krakowski 17(584) (April 24, 2005).

46 "Największa księga kondolencyjna w Polsce,"

http://goscniedzielny.wiara.pl/index.php?grupa $=6 \&$ art $=1114557335 \& d z i$ $=1104746391$ \&idnumeru $=1114031450$.

47 Personal communication from Jan Flasza, Bochnia, Poland, May 21, 2006.

48 Personal observations, Krakow, Poland, May 23, 2006.

49 "Kubek z Papieżem,"

http://goscniedzielny.wiara.pl/index.php?grupa=6\&art=1114576253\&dzi $=1104746391 \&$ idnumeru $=1114031450$.

50 Personal observations, Krakow, Poland, May 22, 2006.

51 Personal observations, Krakow, Poland, May 22, 2006.

52 Personal observations, Wadowice, Poland, May 22, 2006.

53 Personal observations, Wadowice, Poland, May 22, 2006.

54 Personal observations, Zakopane, Poland, May 27, 2006.

55 Personal observations, Zakopane, Poland, May 27, 2006.

56 Personal observations, Zakopane, Poland, May 27, 2006.

\section{BIBLIOGRAPHY}

Banks Thomas, Jeannie. 2006. "Communicative Commemoration and Graveside Shrines: Princess Diana, Jim Morrison, My "Bro" Max, and Boogs the Cat," in Spontaneous Shrines and the Public Memorialization of Death. Jack Santino, ed. New York, N.Y: Palgrave MacMillan, 17-40.

Benet, Sula. 1951. Song, Dance, and Customs of Peasant Poland. London: Dennis Dobson.

Greenhalgh, Susanne. 1999. "Our Lady of Flowers: The Ambiguous Politics of Diana's Floral Revolution," in Mourning Diana: Nation, Culture, and the Performance of Grief. Adrian Kear and Deborah Lynn Steinberg, eds. London and New York: Routledge, 40-59. 
Grider, Sylvia. 2006. "Twelve Aggie Angels: Content Analysis of the Spontaneous Shrines Following the 1999 Bonfire Collapse," in Spontaneous Shrines and the Public Memorialization of Death. Jack Santino, ed. New York, N.Y: Palgrave MacMillan, 215-232.

Hartley, Ralph. 2006. "Signifying Places of Atrocity," in Spontaneous Shrines and the Public Memorialization of Death. Jack Santino, ed. New York, N.Y: Palgrave MacMillan, 285-303.

Johnson, Richard. 1999. "Exemplary Differences: Mourning (and not Mourning) a Princess," in Mourning Diana: Nation, Culture, and the Performance of Grief. Adrian Kear and Deborah Lynn Steinberg, eds. London and New York: Routledge, 15-39.

Klekot, Ewa. 2007. "Mourning John Paul II in the Streets of Warsaw," Anthropology Today 23(4) August.

Kłoczowski, Jerzy. 2000. A History of Polish Christianity. Cambridge: Cambridge University Press.

Maniura, Robert. 2004. Pilgrimages to Images in the Fifteenth Century: The Origins of the Cult of Our Lady of Czestochowa. Woodbridge, UK: Boydell Press.

Paces, Cynthia, and Nancy M. Wingfield. 2005. "The Sacred and the Profane: Religion and Nationalism in the Bohemian Lands, 18801920," in Constructing Nationalities in East Central Europe. Paces, Cynthia, and Nancy M. Wingfield, eds. New York: Berghahn Books, 107-125.

Sánchez-Carretero, Cristina. 2006. "Trains of Workers, Trains of Death: Some Reflections after the March 11 Attacks in Madrid," in Spontaneous Shrines and the Public Memorialization of Death. Jack Santino, ed. New York, N.Y: Palgrave MacMillan, 333-347.

Santino, Jack. 2006. "Introduction," Spontaneous Shrines and the Public Memorialization of Death. Jack Santino, ed. New York, N.Y: Palgrave MacMillan, 1-3.

Santino, Jack. 2006. "Performative Commemoratives: Spontaneous Shrines and the Public Memorialization of Death," in Spontaneous Shrines and the Public Memorialization of Death. Jack Santino, ed. New York, N.Y: Palgrave MacMillan, 5-15.

Senie, Harriet F. 2006. "Mourning in Protest: Spontaneous Memorials and the Sacralization of Public Space," in Spontaneous Shrines and the Public Memorialization of Death. Jack Santino, ed. New York, N.Y: Palgrave MacMillan, 41-56.

The Cultural Center of Wadowice in the name of M. Wadowit. 2005. I looked for you, Now you have come to me: John Paul II at the end 
of his way, Exhibition of the photographs Agence France-Presse, Wadowice, Town Museum, 4 Kościelna Street, At the first anniversary of his death. Wadowice, Poland.

Thoms, Alston. 2000. The Emotion Enigma: “Today's Grief May Help Explain Ancient Funeral Offerings," Discovering Archaeology 2(3) July/August.

Unowsky, Daniel. 2005. The Pomp and Politics of Patriotism: Imperial Celebrations in Habsburg Austria, 1848-1916. West Lafayette, Indiana: Purdue University Press.

Verdery, Katherine. 1999. The Political Lives of Dead Bodies: Reburial and Postsocialist Change. New York: Columbia University Press.

Walsh, Sister Mary Ann, RSM, with Reporting by Catholic News Services. 2005. From Pope John Paul II to Benedict XVI: An Inside Look at the End of an Era, the Beginning of a New One, and the Future of the Church. Lanham, Maryland: Rowman \& Littlefield Publishers, Inc. 